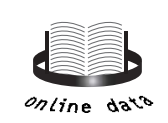

Clinical Science (2010) I I 9, 187-202 (Printed in Great Britain) doi:10.1042/CS2010004I

187

$R \quad E \quad V \quad$ I $E \quad$ W

\title{
DNA repair systems and the pathogenesis of Mycobacterium tuberculosis: varying activities at different stages of infection
}

\author{
Alina E. GORNA* $†$, Richard P. BOWATER $\ddagger$ and Jaroslaw DZIADEK $\dagger$ \\ *Institute of Microbiology, Biotechnology and Immunology, University of Lodz, Lodz 90-23I, Poland, fInstitute for Medical \\ Biology, Polish Academy of Sciences, Lodz 93-232, Poland, and $¥$ School of Biological Sciences, University of East Anglia, \\ Norwich NR4 7TJ, U.K.
}

\section{A}

Mycobacteria, including most of all MTB (Mycobacterium tuberculosis), cause pathogenic infections in humans and, during the infectious process, are exposed to a range of environmental insults, including the host's immune response. From the moment MTB is exhaled by infected individuals, through an active and latent phase in the body of the new host, until the time they reach the reactivation stage, MTB is exposed to many types of DNA-damaging agents. Like all cellular organisms, MTB has efficient DNA repair systems, and these are believed to play essential roles in mycobacterial pathogenesis. As different stages of infection have great variation in the conditions in which mycobacteria reside, it is possible that different repair systems are essential for progression to specific phases of infection. MTB possesses homologues of DNA repair systems that are found widely in other species of bacteria, such as nucleotide excision repair, base excision repair and repair by homologous recombination. MTB also possesses a system for non-homologous end-joining of DNA breaks, which appears to be widespread in prokaryotes, although its presence is sporadic within different species within a genus. However, MTB does not possess homologues of the typical mismatch repair system that is found in most bacteria. Recent studies have demonstrated that DNA repair genes are expressed differentially at each stage of infection. In the present review, we focus on different DNA repair systems from mycobacteria and identify questions that remain in our understanding of how these systems have an impact upon the infection processes of these important pathogens.

\section{INTRODUCTION}

MTB (Mycobacterium tuberculosis), the causative agent of TB (tuberculosis), is a micro-organism that is among the greatest 'enemies' of humanity. According to a WHO (World Health Organization) report from 2009 [1], more than 2 billion people are currently infected with TB bacilli and 1 in 10 of infected people will become sick with active TB during their lifetime. Indeed, in 2008, 1.8 million of people died from TB [1]. Even though several anti-mycobacterial drugs have been discovered and are currently in use, the results of the applied

Key words: aerosol droplet, DNA repair, drug susceptibility infection, macrophage, Mycobacterium tuberculosis, granuloma, mutation rate.

Abbreviations: BCG, Mycobacterium bovis BCG; BER, base excision repair; DSB, double-strand break; HR, homologous recombination; MDR, multi-drug resistant; MMR, mismatch repair; Ms, Mycobacterium smegmatis; MTB, Mycobacterium tuberculosis; NER, nucleotide excision repair; NHEJ, non-homologous end-joining; NOS, NO synthase; ONOO- ${ }^{-}$, peroxynitrite; RNI, reactive nitrogen intermediate; ROI, reactive oxygen intermediate; SNP, single nucleotide polymorphism; SP, surfactant protein; TB, tuberculosis; XDR, extensively drug-resistant.

Correspondence: Dr Jaroslaw Dziadek (email jdziadek@cbm.pan.pl). 
chemotherapy are far from satisfactory. Treatment requires many months of taking several drugs and there are many side effects. The drugs are, in some cases, difficult to obtain and therapeutic regimes are difficult to follow. When coupled with the nature of MTB's infectious process itself, this has resulted in widespread emergence of drug-resistant and multidrug-resistant strains of MTB. Therefore it is of great importance to understand how MTB succeeds in infecting its host, as such advances in knowledge will help the therapeutic fight against this pathogen. Proteins involved in DNA metabolism offer interesting possibilities as drug targets, because many of them provide essential functions to bacteria and, in many cases, are distinct from human proteins at the biochemical and structural level.

The infectious process of MTB can be divided into several stages [2]. Infection begins when bacteria are exhaled by infected individuals and are transported in aerosol droplets through the air. Small numbers of bacteria are then inhaled by healthy individuals and settle as a primary infection that inhabits macrophages. At this point, depending on the efficiency of the host's immune response, bacteria may be eradicated from the host organism. However, if the host's response is insufficient, macrophage-residing mycobacteria inhibit the fusion of phagosomes and lysosomes and, following the primary infection stage, may enter a stage of latency in the form of a granuloma. Several types of cells are recruited to the site of infection, including lymphocytes, monocytes and neutrophils, and they cluster together to form a closed environment where the mycobacteria may reside for decades. MTB resides in a state of latency until the moment when there is the breakage of the granuloma and reactivation of the disease (Figure 1). Important details about each phase of the infection process will be discussed below.

As mycobacteria are exposed constantly to hostile environments, which, among other things, lead to lesions and modifications of the bacterial DNA, the integrity of its genome is protected by mechanisms of DNA repair [3]. These mechanisms are important to consider in the context of mycobacteria because they could influence processes leading to drug resistance and they may offer novel targets for antibiotics [4]. Mycobacteria possess DNA repair systems common to prokaryotes, such as HR (homologous recombination), BER (base excision repair) and NER (nucleotide excision repair). Mycobacteria also possess a system for NHEJ (nonhomologous end-joining) of DNA breaks, which is widespread in prokaryotes, although its presence is sporadic within different genera of bacteria. However, in contrast with many other prokaryotes, mycobacteria do not possess mechanisms known to be required for MMR (mismatch repair) [5]. A description of the specific roles of each protein involved in DNA repair exceeds the space available within the present review; however,

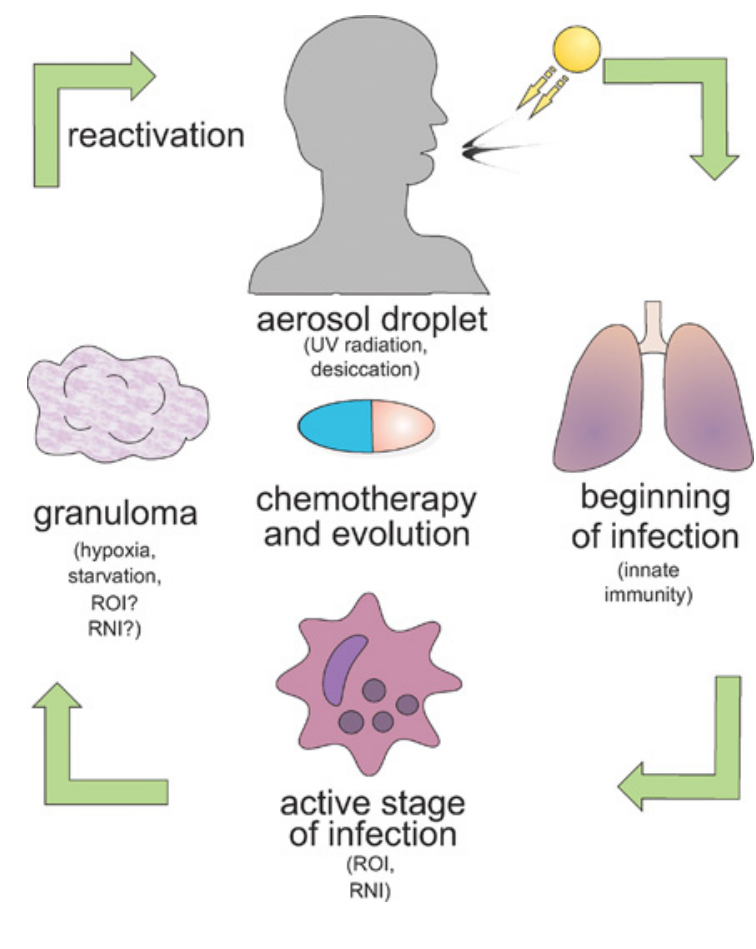

Figure I Overview of the MTB infection process in humans Infection of humans by MTB occurs via several distinct stages. At each stage of infection, the bacteria are exposed to various types of stress that may induce different types of DNA damage.

several recent reviews have covered mycobacterial DNA repair proteins $[4,6,7]$.

Microarray analysis has revealed that almost half of the MTB DNA repair genes are continuously expressed during exponential phase growth in broth, suggesting that the bacteria have to continuously counteract the constant exposure to DNA-damaging agents [8] (see Supplementary Table S1 at http:// www.clinsci.org/cs/119/cs1190187add.htm). Intriguingly, only a few of the genes associated with DNA repair are required for optimal growth of MTB in broth, including Rv2554c, dut, lig $A$, polA, $a d n B$ and those encoding the NER-related proteins UvrD1, UvrD2 and UvrC [9] (see Supplementary Table S1). In fact uvrD2 [10] and $\operatorname{lig} A$ [11] have been shown to be essential for the survival of Ms (M. smegmatis), a non-pathogenic saphrophytic bacteria found mostly in soil, water or plants worldwide and used as a genetic model for the Mycobacterium genus. Another MTB study identified that survival in vivo in mice required three BER proteins (Ung, Nfo/End and XthA), MazG and RecN [12]. Most of the MTB DNA repair genes have been shown to be non-essential for survival in broth, but the growth of a strain defective in recA was slowed down [9] (see Supplementary Table S1). Independent of the probable constitutive expression of DNA repair genes, their expression changes in response to different environments encountered during the process 
of infection. Thus, as we discuss below, in vitro and in vivo studies provide us with an insight into the role of DNA repair proteins in the pathogenesis of MTB at different stages of infection. For more information see Supplementary Table S1.

\section{AEROSOL DROPLETS}

MTB is transmitted in aerosol droplets, which are coughed out by infected individuals. The size distribution of the aerosol droplets is variable, but most particle sizes are within the size that can be taken into the respiratory system [13]. Experiments performed in 1969 reported that the rate of survival of mycobacteria in aerosol droplets falls to $50 \%$ after $6 \mathrm{~h}$ [14]. More recent findings have shown that, if MTB is held for $5 \mathrm{~min}$ in an aerosol of artificial saliva, its viability declines to $55 \%$, after 30 min less than $10 \%$ remain viable and after $1 \mathrm{~h}$ the percentage of viable cells is close to zero [15]. The authors of that study point out that the viability of MTB might actually be further compromised because of another factor influencing survival of mycobacteria in the natural environment, namely UV radiation. In fact UV radiation, apart from being present in the natural environment, is a known agent for sterilizing mycobacteria-contaminated air [16-18]. Environmental studies highlight the importance of both factors in the survival of mycobacteria; for example, lower transmission rates of TB are observed at higher altitudes, where humidity is low and the exposure to UV light is stronger [19]. Studies based on artificially generated droplets carrying BCG (M. bovis BCG), the causative agent of TB in cattle, show a link between both factors: increased UV resistance is observed at high relative humidity [20]. Nevertheless, it is clear that the survival rate of mycobacteria is drastically reduced when they remain in the aerosol droplet, especially if it is exposed to environmental conditions such as desiccation and UV irradiation.

It is known that both desiccation and UV radiation lead to DNA damage. Intracellular dehydration leads to DSBs (double-strand breaks) of DNA, but also DNA conformation changes and, as a result, a different susceptibility to UV-induced DNA damage [21]. UV exposure leads to cyclobutane pyrimidine dimers and pyrimidine(6-4)pyrimidine photoproducts, in which two adjacent pyrimidines are covalently linked. It also leads to some damage of bases, producing cytosine hydrate and thymine glycol. Thus it is clear that, in order to survive the 'outside host' environmental stage of their life cycle, mycobacteria must employ DNA repair systems. However, currently it remains uncertain whether DNA repair is active while the mycobacteria are still suspended in aerosol droplets or when they inhabit their new host.
Desiccation of mycobacteria leads to DSBs in their DNA and, if unrepaired, these can be lethal to the cells in which they occur. There are two systems in mycobacteria known to repair this kind of DNA damage: HR and NHEJ. Construction of mutant strains of Ms lacking the proteins RecA (for HR) and Ku and/or LigD (for NHEJ) showed that neither system of DSB repair is essential for growth in vitro [11]. However, both systems are required to maintain the viability of Ms under desiccation in the broth culture (Table 1) and, interestingly, the susceptibility to desiccation of the mutant lacking both HR and NHEJ did not vary from the susceptibility of strains that were defective for only NHEJ or HR [22]. Whether such an outcome is a result of an interplay between NHEJ and HR while repairing DSBs, or the susceptibility of the RecA mutant is due to the disruption of other cellular pathways, such as the SOS response, is still unknown. Notably, differences in the environmental niches of Ms and MTB must be taken into consideration when assessing these data.

The core mechanism for removal and repair of UVinduced damage is NER. It consists of the UvrABC nuclease enzyme complex and the $\mathrm{UvrD}$ helicase. Mutations that influence NER, including polA of Ms [23], uvrB for both Ms [24] and MTB [25] and uvrD1 of Ms [26], lead to increased susceptibility to UV radiation in vitro (Table 1). Interestingly, the combined deletion of both $u v r B$ and $u v r D 1$ of Ms has an additive effect on the survival rate of mycobacteria under UV radiation [26]. Such a result implies an involvement for both gene products in NER, but also suggests that one of the proteins has an additional role in another DNA repair pathway. Which other repair systems could be involved in UV damage repair? During broth growth, UvrD1 has been reported to be an interaction partner for Ku protein, one of the major proteins in NHEJ. Nevertheless, UvrD1 function in UV damage repair seems to be independent of $\mathrm{Ku}$, as a $\mathrm{Ku}$-deficient strain of Ms displays wild-type sensitivity to UV radiation $[27,28]$.

Another type of DNA metabolism that is important for the repair of UV-induced damage in vitro is HR. MTB RecA is induced in Ms broth culture following UV exposure [29], and mutation in recA makes this Ms mutant increasingly susceptible to UV irradiation [26,30]. However, neither the effect of a double mutation in NER and HR under UV-induced stress nor the relationship between HR and NER proteins in mycobacteria is completely understood.

Microarray analysis of MTB genes induced under UV treatment in broth cultures confirmed the role of HR and NER in the repair of such damage. It also highlighted several other possible proteins that could be involved in such repair, including Ogt, Ada/AlkA, DinF, Lhr, DinX and DnaE2 [31,32]. It has to be underlined, though, that two independent studies did not produce fully consistent results [31,32] (see Table 1). Another puzzling observation 
Table I DNA repair genes affected by UV or desiccation

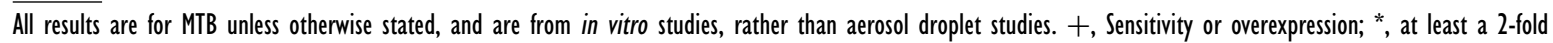
change in expression level.

\begin{tabular}{|c|c|c|c|c|c|}
\hline Locus & Gene & Induced by UV in MTB [3I]* & Induced by UV in MTB [32] & Mutants sensitive to UV exposure & Mutants sensitive to desiccation in Ms [22] \\
\hline Rv0937c & ku & & & & + \\
\hline Rv0938 & $\operatorname{lig} D$ & & & & + \\
\hline Rv0949 & uvrDI & & & Ms $+[26]$ & \\
\hline Rvl3I6c & ogt & & + & & \\
\hline Rvl3I7c & ada, alkA & & + & & \\
\hline $\operatorname{Rv} 1629$ & polA & & & Ms $+[23]$ & \\
\hline $\operatorname{Rvl} 633$ & uvr $B$ & & + & $+[25] ;$ Ms $+[24]$ & \\
\hline Rvl638 & uvrA & & + & & \\
\hline $\operatorname{Rv} 2593 \mathrm{C}$ & ruvA & & + & & \\
\hline $\operatorname{Rv} 2594 \mathrm{c}$ & ruvc & + & + & & \\
\hline Rv2697c & $d u t$ & & & & \\
\hline $\operatorname{Rv} 2719 \mathrm{c}$ & & + & & & \\
\hline $\operatorname{Rv} 2720$ & lexA & & + & & \\
\hline Rv2736c & reck & + & + & & \\
\hline Rv2737c & recA & + & + & Ms $+[26,30]$ & + \\
\hline $\operatorname{Rv} 3198 \mathrm{c}$ & uvrD2 & & + & & \\
\hline Rv3202c & $\operatorname{adn} A$ & & + & & \\
\hline Rv3296 & Ihr & & + & & \\
\hline $\operatorname{Rv} 3370 \mathrm{c}$ & $d n a E 2$ & & + & & \\
\hline Rv3394c & $\operatorname{din} X$ & & + & & \\
\hline Rv3395c & $\operatorname{din} F$ & + & & & \\
\hline $\operatorname{Rv} 3585$ & $\mathrm{radA}$ & & + & & \\
\hline
\end{tabular}

relates to the presence of MTB KatG catalase-peroxidase with resistance to UV damage, since an Escherichia coli recA-deficient strain carrying MTB kat $G$ had higher survival rates under exposure to UV radiation in broth culture [33]. The observed phenomenon was not due simply to catalase-peroxidase activity. On the other hand such an effect was not observed in tubercule bacilli clinical strains [33]. However, $k a t G$ is induced by UV radiation, as identified in broth culture analysis of MTB [31].

\section{MACROPHAGE INFECTION}

The second stage of infection by mycobacteria starts as soon as they are inhaled by a healthy individual. This stage proceeds by the bacteria inhabiting and residing in macrophages, eventually forming a granuloma. From this point on the mycobacteria are continuously exposed to both oxidative and nitrosative stress generated by the activated macrophages that they inhabit [34].

Macrophages produce ROIs (reactive oxygen intermediates) and RNIs (reactive nitrogen intermediates) as cytotoxic agents in the immune response to pathogens. Production of these compounds by host cells appears to be essential in the control of mycobacterial infection, as murine mutants deficient in NOS (NO synthase) responsible for producing RNIs [34-36] or phagocyte oxidase cytochrome $b$ responsible for producing ROIs [34] experience exaggerated mycobacterial infection. The mutagenic effect and cytotoxic effect of ROIs and RNIs is based on several chemical reactions leading to DNA damage. $\mathrm{NO}$ can undergo auto-oxidation to form $\mathrm{N}_{2} \mathrm{O}_{3}$ (nitrous anhydrate), which can nitrosinate amines to $\mathrm{N}$-nitrosamines, which, after activation, alkylate DNA through an indirect mechanism [37]. Direct nitrosation of DNA bases leads to the formation of diazonium ions and subsequent deamination, which can result in base transitions, transversions and cross-links. Moreover, deamination of guanine leads to the formation of xanthine, which is unstable in DNA and can depurinate easily, leaving an abasic site that can be cleaved by endonucleases to generate single strand breaks. NO can also react with superoxide giving rise to $\mathrm{ONOO}^{-}$ (peroxynitrite), a compound which causes more severe DNA damage at smaller doses than $\mathrm{NO}$. $\mathrm{ONOO}^{-}$can nitrate DNA, resulting in the damage described above, but it can also oxidize it [37]. Even though oxidation can occur on all four bases of DNA, the most common DNA lesion that is used as a marker of oxidative stress is the formation of 8-hydroxyguanine [38]. Oxidized bases can sometimes be pro-mutagenic and, since some can block replication forks, they can be lethal [39]. 
One of the first lines of defence against pathogens invading the respiratory tract is the surfactant of the lungs. Within the fluid, SPs (surfactant proteins) are responsible for interacting with incoming pathogens. Of particular interest, SP-A increases phagocytosis of BCG [40] and, while in complex with BCG, has been shown to stimulate expression of NOS by rat alveolar macrophages [41]. However, contact with surfactant itself, without the presence of macrophages, seems to have a minor effect on the expression of DNA repair genes in MTB. Results from a transcriptional analysis of the response of MTB to bovine lung surfactant show that only one DNA repair gene, mut $Y$, was up-regulated upon contact with bovine lung surfactant, whereas a few, including $n t h, \operatorname{Rv} 1160$, Rv0944 and ercc3, were down-regulated [42].

Several studies have confirmed the role of mycobacterial proteins involved in NER and BER in the removal of damage encountered in macrophages (Table 2). Interestingly, the MTB gene adalalk $A$ was up-regulated in both human [43] and murine [44] macrophages and upregulated in response to $\mathrm{H}_{2} \mathrm{O}_{2}$ in broth culture $[32,44]$. Furthermore, MTB strains deficient in adalalkA had increased susceptibility to RNIs, but the gene seems to be irrelevant for MTB during survival in mice, as the knockout mutant had a wild-type survival rate [45]. Further interesting observations have been made in relation to $\operatorname{nvr} B$, which is required for optimal growth of MTB in mice [25]. Two studies showed, using different reagents and methods, that Ms with $u v r B$ knocked out were more susceptible to ROIs than the wild-type in broth culture $[24,26]$. However, experiments in MTB, performed using a disc diffusion assay on agar plates [25] and in broth cultures [45a] but performed with slight modifications of the methods in relation to the studies performed in Ms, produced contradictory results. The differences in the results obtained in Ms and MTB may be a result of the different approaches used by the authors; however, deletion of $u v r B$ in both MTB and Ms increased their susceptibility to RNIs in broth cultures (Table 2).

Microarray experiments suggest that HR genes are expressed during the active phase of infection (Table 2). MTB genes involved in this type of repair were upregulated within murine macrophages or in response to $\mathrm{H}_{2} \mathrm{O}_{2}$ [44] and also in human macrophages [46]. However, microarray experiments following phagocytosis by human and murine macrophages suggest possible differences between the macrophage environments of the two species. The pattern of gene expression in both studies was different, most notably seen in the case of $\operatorname{rec} X$, as it was up-regulated in murine macrophages [44,47], but down-regulated after $4 \mathrm{~h}$ of human macrophage infection [43] (Table 2).

Studies have reported that expression of the NHEJ major proteins is unaltered in response to the environment encountered in macrophages. However, since the core NHEJ proteins are constitutively expressed in MTB during exponential growth in the broth culture [8], NHEJ might still play an important role at this stage of infection. Taken together, the combined results suggest that DSBs occurring in mycobacteria at this stage of infection might be preferentially repaired by HR. However, it is notable that a recA-deficient mutant of BCG does not influence the bacteria's rate of survival in vivo in a mouse model, even though it shows increased susceptibility to DNA alkylating agents in vitro [48]. Thus there is still much to learn as to whether DSBs within the mycobacterial genome influence the infection of macrophages. For more information regarding the DNA repair gene response during the active stage of infection of MTB, see Table 2.

\section{GRANULOMA}

After the active phase of infection is over, mycobacteria persist in the infected lung and settle in to cause a chronic infection. Constant antigenic stimulation and accumulation of T-cells leads to the formation of a granuloma, which can maintain viable bacilli for decades.

The architecture and environment of granulomas vary between different organisms [49]. The structure of a human granuloma is characterized by a central region of large $\mathrm{CD}^{2} 8^{+}$epitheloid cells, surrounded by macrophages, T-lymphocytes (predominantly $\mathrm{CD}^{+}$) and multi-nucleate giant Langerhans cells. In mice there is a co-location of $\mathrm{CD}^{+}{ }^{+} \mathrm{T}$-cells and macrophages, some of which differentiate into epitheloid cells, but the giant Langerhans cells are absent. In both organisms there is the presence of B-lymphocyte aggregates, but their spatial relationship with other immune cells is different. Another distinctive feature of human granulomas is caseous necrosis, which is also absent in the murine version. This is a central acellular eosinophilic region of granuloma formed as a result of cells undergoing necrosis and/or apoptosis under intense cytokine and direct cell-cell activation. The central region of the granuloma does not contain blood vessels and becomes hypoxic [49], a feature not observed in the murine model [50]. Hypoxia then further increases the chances for cells to undergo necrosis [49]. As the granuloma becomes necrotic, it may either be resolved by fibrosis and calcification or become liquefied, therefore leading to dissemination of any pathogens contained within it. Details about granuloma formation and deconstruction have been reviewed previously [51].

There is still an ongoing discussion as to whether MTBs undergo cell division when they are inside granulomatous tissue $[52,53]$. Nevertheless, it seems that MTBs have varying gene expression within granuloma. An important aspect in terms of DNA repair is that the environment of a granuloma is hypoxic and hypoxia leads to DNA damage $[54,55]$. As identified by in vitro 
Table 2 Active phase of infection-affected genes

All results are for MTB, unless otherwise described. $+/-$, Mutant increasingly susceptible or up-regulated gene/mutant presenting wild-type susceptibility or down-regulated gene; *, at least a $I .8-$-fold change in expression level; $\dagger$, for more data, see reference. SCID, severe combined immunodeficiency; vs., versus.

\begin{tabular}{|c|c|c|c|c|c|c|c|c|c|c|}
\hline \multirow[b]{3}{*}{ Locus } & \multirow[b]{3}{*}{ Gene } & \multicolumn{4}{|l|}{ Mutant analysis } & \multicolumn{5}{|l|}{ Expression analysis } \\
\hline & & & \multirow[b]{2}{*}{$\begin{array}{l}\text { Decreased survival } \\
\text { rate in mice vs. } \\
\text { wild-type }\end{array}$} & \multicolumn{2}{|l|}{ Broth culture } & \multicolumn{2}{|l|}{ Murine } & \multirow{2}{*}{$\begin{array}{l}\text { Human } \\
\text { Macrophages }\end{array}$} \\
\hline & & $\begin{array}{l}\text { RNIs vs. wild-type } \\
\text { in vitro }\end{array}$ & $\begin{array}{l}\text { ROls vs. wild-type } \\
\text { in vitro }\end{array}$ & $\begin{array}{l}\text { Alkylating agents } \\
\text { vs. wild-type } \\
\text { in vitro }\end{array}$ & & $\begin{array}{l}\mathrm{H}_{2} \mathrm{O}_{2} \text { treated vs. } \\
\text { untreated culture }\end{array}$ & $\begin{array}{l}\text { Response to bovine } \\
\text { surfactant or or its } \\
\text { components [42]† }\end{array}$ & Macrophages & $\begin{array}{l}\text { Whole-animal } \\
\text { studies }\end{array}$ & \\
\hline Rv0054 & $s s b$ & & & & & $+[32]$ & & & & \\
\hline Rv04I3 & mutT3 & & & & & & & & $+(\mathrm{BALB} / \mathrm{C}$ and SCID mice) [47] & $+[108]$ \\
\hline $\mathrm{Rv063 \textrm {IC }}$ & $\mathrm{rec} C$ & & & & & & & & + (only in SCID mice) [47] & $+[108]$ \\
\hline Rv086lc & $\operatorname{ercc} 3$ & & & & & & - & & & \\
\hline Rv0944, & nei2 & & & & & & & & & \\
\hline Rv0949 & uvrDI & Ms $+[26]$ & Ms $+[26]$ & & & & & & & \\
\hline Rvl020 & $m f d$ & & & & & & & $+[109]$ & + (only in SCID mice) [47] & \\
\hline Rvll 60 & mutT2 & & & & & & - & & & \\
\hline RvI210 & $\operatorname{tag} A$ & & & & & & & & & \\
\hline Rvl259 & $u d g B$ & Ms $+[110]$ & & & & & & & & $+[43]$ \\
\hline Rvl316c & ogt & $+[45]$ & & $-[45]$ & & $+[32,44]^{*}$ & & & & \\
\hline Rvl3I7c & ada, alkA & $+[45]$ & & $-[45]$ & & $+[32,44]^{*}$ & & $+[44]^{*}$ & & $+[43]$ \\
\hline Rvl329c & $\operatorname{din} G$ & & & & & & & $+[109]$ & & \\
\hline $\operatorname{Rv} 1420$ & uvrC & & & & & & & & & $+[46]$ \\
\hline Rvl629 & polA & & Ms + [23] & & & & & & + (only in SCID mice) [47] & \\
\hline Rvl633 & uvrB & $+[25]$, Ms $+[24,26]$ & $-[25,115], M s+[24,26]$ & & $+[25]$ & $+[32]$ & & & & \\
\hline Rvl638 & uvrA & & & & & $+[32]$ & & & & $+[113]$ \\
\hline $\operatorname{Rv} 2090$ & & & & & & & & $+[109],+[44]^{*}$ & & \\
\hline $\operatorname{Rv} 2191$ & & & & & & & & $+[44]^{*}$ & & \\
\hline $\operatorname{Rv} 2592 \mathrm{c}$ & ruvB & & & & & & & & + (SCID mice and broth) [47] & \\
\hline $\operatorname{Rv} 2593 \mathrm{C}$ & ruvA & & & & & & & & & $-[43]$ \\
\hline
\end{tabular}


Table 2 (Contd).

\begin{tabular}{|c|c|c|c|c|c|c|c|c|c|c|}
\hline \multirow[b]{3}{*}{ Locus } & \multirow[b]{3}{*}{ Gene } & \multicolumn{4}{|l|}{ Mutant analysis } & \multicolumn{5}{|l|}{ Expression analysis } \\
\hline & & \multicolumn{3}{|l|}{ Sensitive to } & \multirow[b]{2}{*}{$\begin{array}{l}\text { Decreased survival } \\
\text { rate in mice vs. } \\
\text { wild-type }\end{array}$} & \multicolumn{2}{|l|}{ Broth culture } & \multicolumn{2}{|l|}{ Murine } & \multirow{2}{*}{$\begin{array}{l}\text { Human } \\
\text { Macrophage }\end{array}$} \\
\hline & & $\begin{array}{l}\text { RNIs vs. wild-type } \\
\text { in vitro }\end{array}$ & $\begin{array}{l}\text { ROls vs. wild type } \\
\text { in vitro }\end{array}$ & $\begin{array}{l}\text { Alkylating agents } \\
\text { vs. wild-type } \\
\text { in vitro }\end{array}$ & & $\begin{array}{l}\mathrm{H}_{2} \mathrm{O}_{2} \text { treated vs. } \\
\text { untreated culture }\end{array}$ & $\begin{array}{l}\text { Response to bovine } \\
\text { surfactantor or its } \\
\text { components [42] } \dagger\end{array}$ & Macrophages & $\begin{array}{l}\text { Whole-animal } \\
\text { studies }\end{array}$ & \\
\hline $\operatorname{Rv} 2697 \mathrm{c}$ & $d u t$ & & & & & & & & & $+[46]$ \\
\hline $\operatorname{Rv} 2719 c$ & & & & & & $+[44]^{*}$ & & $+[44]^{*}$ & & \\
\hline $\operatorname{Rv} 2736 \mathrm{c}$ & reck & & & & & $+[32,44]^{*}$ & & $+[44]^{*}$ & + (only in SCID mice) [47] & $-[43]$ \\
\hline Rv2737c & recA & Ms - [26] & Ms $+[26]$ & $B C G+[48]$ & $B C G-[48]$ & $+[32,44]^{*}$ & & & & \\
\hline $\operatorname{Rv} 2836 c$ & $\operatorname{dinF}$ & & & & & & & $+[109]$ & $+(B A L B / C$ and SCID mice) $[47]$ & \\
\hline $\operatorname{Rv} 2922 \mathrm{c}$ & $s m c$ & & & & & & & & + (only in SCID mice) [47] & \\
\hline $\operatorname{Rv} 2924 c$ & mutM, $f p g$ & Ms - [24] & Ms $+[24, I 12]$ & & & & & & & \\
\hline Rv2973c & $\operatorname{recG}$ & & & & & & & $+[44]^{*}$ & & \\
\hline $\operatorname{Rv} 2976 \mathrm{c}$ & ung & Ms $+[24, \mathrm{II} 0, \mathrm{III}]$ & Ms $+[24]$ & & & & & & & \\
\hline $\operatorname{Rv} 3014 c$ & $\operatorname{lig} A$ & & & & & & & & + (only in BALB/C mice) [47] & \\
\hline $\operatorname{Rv} 3202 c$ & $\operatorname{adn} A$ & & & & & $+[32,44]^{*}$ & & $+[44]^{*}$ & & \\
\hline $\operatorname{Rv} 3296$ & Ihr & & & & & $+[44]^{*}$ & & $+[44]^{*}$ & & \\
\hline Rv3394c & $\operatorname{din} X$ & & & & & $+[32]$ & & & & \\
\hline $\operatorname{Rv3585}$ & $\operatorname{radA}$ & & & & & $+[32,44]^{*}$ & & $+[44]^{*}$ & & \\
\hline $\operatorname{Rv3589}$ & muTY & & Ms $-[93]$ & & & & + & & & \\
\hline $\operatorname{Rv} 3674 c$ & nth & & & & & & - & & & \\
\hline $\operatorname{Rv} 3715 \mathrm{c}$ & reck & & & & & & & $-[44]^{*}$ & & \\
\hline
\end{tabular}


broth culture studies, several DNA repair genes of MTB are induced or repressed under hypoxic conditions [5659] (for detailed information, see Supplementary Table S2 at http://www.clinsci.org/cs/119/cs1190187add.htm). However, even though there is a general trend for the down-regulation of DNA repair genes under such conditions, gene expression in different experiments differ greatly from one another. These results highlight that gene expression of mycobacteria might depend not only on their current conditions, but also on the way they achieved such a state, meaning that the results obtained by different methods might not be entirely comparable.

Another factor that influences the survival of mycobacteria in a granuloma is starvation. It has been shown that the response to such an environment is very quick; after $4 \mathrm{~h}$ of incubation in PBS several genes changed their expression, including $x$ se $A$, which was down-regulated, and mutT2 (Rv1160), which was up-regulated [60]. In long-term cultures (104 days) depleted of nutrients, several genes of MTB underwent changes in their expression profiles [61]. Some genes were maintained as being either up-regulated ( $n f o$, adalalkA, ogt and $\mathrm{Rv} 2554 \mathrm{c}$ ) or down-regulated (recN, Rv0269c, Rv2191 and $m p g$ ) for the extended period of time; however, most of the genes underwent several changes in their expression profiles (Supplementary Table S2). It was postulated that the change in expression profile at day 18 was a result of the stringent response as carbon sources were utilized, whereas at day 75 the population was progressing towards cell division, but changes in the expression profiles of DNA repair genes also occurred at other times [61].

Another factor that is probably encountered by mycobacteria within a granuloma is $\mathrm{NO}$ and related RNIs. Several lines of evidence suggest that NO is released in the lungs of people chronically infected with MTB (for more details, see [62]). Intriguingly, nontoxic concentrations of $\mathrm{NO}$ inhibit aerobic respiration and growth and, together with limited amounts of oxygen, prepare bacilli for survival in dormancy [63]. No DNA repair genes were up-regulated during exposure of mycobacteria to non-toxic concentrations of NO. Thus any influence of NO over DNA repair pathways in granulomas remains to be established.

In vitro studies of Ms deficient in DNA repair genes showed that ung- and uvrB-deficient mutants had increased sensitivity to hypoxia in broth culture [24]. Interestingly, comparison of mutant strains deficient in NHEJ and HR revealed that DSBs, at least those caused by ionizing radiation in the stationary phase, are preferentially repaired by NHEJ $[22,28]$. By contrast, a recA-deficient genotype of BCG did not affect growth in broth culture after oxygen depletion nor did it influence survival in BALB/C mice [48]. However, recAdeleted BCG harvested in oxygen-depleted medium had increased susceptibility to metronidazole, an antibiotic effective only with anaerobic bacteria, suggesting that
recA might have a role in maintaining genome stability at chronic stages of infection [48].

In vivo whole-genome studies bring additional important data about the influence of DNA repair genes during infection with MTB. Within artificial granulomas of mice (hollow fibre model), wvrA and recF became up-regulated [64]. In vivo studies in a rabbit model did not confirm these results as the only DNA repair gene that significantly changed its expression during latency, reactivation and immune reconstitution was Rv2191 [65]. Note that a hollow fibre applied by Karakousis et al. [64] allows the formation of an artificial granuloma carrying tubercle bacilli extracellularly, in contrast with a natural granuloma, where MTB is maintained within macrophages. Mice infected with a low dose of aerosolized MTB developed a persistent infection, which became chronic around days 45-60 of infection [66]. The results indicated that mycobacteria remained active, especially during the middle phase of chronic TB. At 60 days post-infection, $\operatorname{bup} B$ and $\mathrm{recO}$ were down-regulated and ung was up-regulated [66]. This expression profile was different from the profile encountered at the active stage of infection (day 15). Thus, while residing in granulomatous tissue, mycobacteria undergo several changes in their gene expression profiles (for more details see Table 3 and Supplementary Table S2).

Reactivation of infection begins when granulomas fail, and there are two main reasons for this phenomenon. One is the failure of the essential formation and maintenance of co-location signals from macrophages and T-cells, despite the presence of other responses that suggest the T-cells remain effective. The other reason relates to a decline in the host's immunity, which may result from the genetic susceptibility of the host or from environmental reasons, such as co-infection with HIV [51]. Little is known about the role of mycobacterial DNA repair genes in reactivation of infection; however, it seems that at least some of them are important for ensuring the survival of the bacteria. One such gene is $\operatorname{wor} B$, as an Ms strain deleted for this gene is compromised in its recovery from hypoxia in broth culture [24]. In vivo studies of dexamethasone-treated $\mathrm{BALB} / \mathrm{C}$ mice, in which mice were undergoing immune suppression, revealed that expression of MTB genes ogt, $\operatorname{din} G$ and recA were increased during reactivation [66]. Ung was up-regulated in the same experiment; however, it was also up-regulated in mice that were not undergoing immune suppression, and therefore presenting chronic TB.

Genome-wide expression analysis of mycobacteria from clinical human lung samples also confirmed the expression of tubercle bacilli DNA repair genes [67] (for more details, see Table 3 and Supplementary Table S2). Interestingly, even though the gene expression profiles of all isolates were similar, the profiles of up-regulated DNA repair genes were different in granuloma, pericavity and 
Table 3 MTB DNA repair genes up-regulated in granulomas in vivo

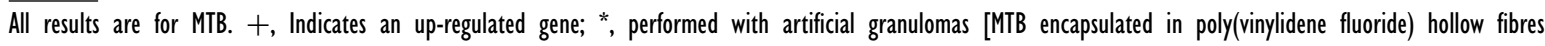
implanted into the subcutaneous space]; $\dagger$, results are on the basis of the supplementary material provided with the article, for more information see [67]. vs., versus.

\begin{tabular}{|c|c|c|c|c|c|c|c|c|}
\hline \multirow[b]{2}{*}{ Locus } & \multirow[b]{2}{*}{ Gene } & \multirow[b]{2}{*}{$\begin{array}{l}\text { Mouse } \\
{[64]^{*}}\end{array}$} & \multicolumn{2}{|l|}{ Mouse [66] } & \multirow[b]{2}{*}{$\begin{array}{l}\text { Rabbit } \\
{[65]}\end{array}$} & \multicolumn{3}{|c|}{ Human [67]† } \\
\hline & & & $\begin{array}{l}\text { BALB/C mice at } \\
45 \text { vs. } 15 \text { days }\end{array}$ & $\begin{array}{l}\text { BALB/C vs. broth } \\
\text { at } 60 \text { days }\end{array}$ & & $\begin{array}{l}\text { Granuloma } \\
\text { vs. broth }\end{array}$ & $\begin{array}{l}\text { Pericavity/distant } \\
\text { lung vs. granuloma }\end{array}$ & $\begin{array}{l}\text { Pericavity/distant } \\
\text { lung vs. broth }\end{array}$ \\
\hline $\mathrm{Rv} 0003$ & recF & + & & & & & & \\
\hline Rv0937c & $k u$ & & & & & + & & \\
\hline Rvl638 & uvrA & + & & & & & & \\
\hline $\operatorname{Rv} 2090$ & & & & & & + & + & + \\
\hline $\operatorname{Rv} 2191$ & & & & & + & & & \\
\hline $\operatorname{Rv} 2593 \mathrm{C}$ & ruvA & & & & & & + & \\
\hline $\operatorname{Rv} 2836 \mathrm{C}$ & $\operatorname{din} F$ & & & & & & + & + \\
\hline Rv2976c & ung & & & + & & & & \\
\hline Rv320IC & $\operatorname{adn} B$ & & + & & & & & \\
\hline $\operatorname{Rv} 3394 \mathrm{c}$ & $\operatorname{din} X$ & & & & & + & & \\
\hline
\end{tabular}

distant lung tissue and only Rv2090 was up-regulated in all three of these isolates. The observed differences could be a result of differential physiology within the cells, but also because the pericavity and distant lung are exposed to air, leading to a heterogenous environment for the mycobacterial samples.

\section{MYCOBACTERIA, CHEMOTHERAPY AND EVOLUTION}

One current important aspect of research into the pathogenesis of mycobacteria relates to the influence of added chemicals. An environment containing selective antibiotics promotes the occurrence of mutations in the pathogen's genome $[68,69]$. Consistent with these findings is the occurrence of drug-resistant strains of MTB, which have been divided into two main groups. MDR (multi-drug resistant) strains are resistant to two front line drugs, isoniazid and rifampicin, and these strains have been estimated to cover $5.3 \%$ of all new cases of TB around the world [1]. XDR (extensively drugresistant) strains are resistant to isoniazid and rifampicin plus one of the fluoriquinolones and at least one second-line injectable drug (capreomycin, kanamycin or amikacin). Even though it is still to be established whether MTB possess plasmids [70,71] and if there is a functional conjugational apparatus in MTB [72,73], up to now all drug-resistance determinants are thought to be chromosomally encoded and to be a result of spontaneous nucleoid mutations [74] or gene inactivation by a mobile genetic element [75]. Mutations are acquired mainly by deletions, insertions or single nucleotide alterations or SNPs (single nucleotide polymorphisms). Acquired resistance towards anti-tubercular compounds has been shown to occur in a single SNP in drug target genes, including $r р о B$ [76-78], kat $G[76,77,79,80]$ and various others [81-86]. MTB harbours relatively little genetic diversity [5,87-89], but findings have shown that diversity between closely related strains may be greater than anticipated and it may be biologically significant [74,90]. Importantly, a larger amount of SNP diversity has been observed in XDR strains [91].

As in all organisms, DNA repair genes directly influence the rates and types of mutation that occur in mycobacteria. When they are functioning properly, these systems help maintain mutation rates at a low level, but in various circumstances they can increase the prevalence of specific types of mutations. First, DNA repair systems might not be efficient enough to repair large amounts of DNA damage, which can therefore lead to mutations. Secondly, some DNA damage repair systems, such as NHEJ [28] or translesion synthesis by DnaE2 [32,92], are error-prone and the repair pathway can lead directly to mutated sequences. Finally, mutations to DNA damage repair proteins can lead to an increase in the mutation rate, as has been observed upon deletion of $u n g, u v r B$, $u v r D, f p g$ and $u d g B$ in $\mathrm{Ms}$ and adalalkA together with ogt in MTB (Table 4 and Supplementary Table S3 at http://www.clinsci.org/cs/119/cs1190187add.htm). Furthermore, mut $Y$ [93] and mutT1 [94] mutations have been observed in drug-resistant phenotypes. Analysis of isoniazid-resistant strains has suggested that the SNPs responsible for resistance had arisen independently [82].

Certain genotypes of mycobacteria are particularly prone to acquiring mutations that result in drug resistance. SNPs seem to be a driving force for two common drug-resistant lineages of MTB, W-Beijing and Haarlem. Both of these strains are extremely fit for 
Table 4 Response of DNA repair genes to chemotherapy by first- and second-line drugs and the influence on mutation acquisition

All results are for MTB, unless otherwise stated. $+/-$, Indicates an up-regulated gene or an increased mutation rate in a deficient mutant/down-regulated gene; *, performed with artificial granulomas [MTB encapsulated in poly(vinylidene fluoride) hollow fibres, implanted into the subcutaneous space]; $\dagger$, at least a 2 -fold change in expression level compared with untreated cultures.

\begin{tabular}{|c|c|c|c|c|c|c|c|c|c|c|c|c|c|}
\hline \multirow[b]{2}{*}{ Locus } & \multirow[b]{2}{*}{ Gene } & \multirow[b]{2}{*}{$\begin{array}{l}\text { Izoniazyd } \\
\text { [103] }\end{array}$} & \multicolumn{4}{|l|}{ Izoniazyd [106] } & \multirow[b]{2}{*}{$\begin{array}{l}\text { Capreomicine } \\
{[104]}\end{array}$} & \multirow[b]{2}{*}{$\begin{array}{l}\text { Rifampicin } \\
{[31] \dagger}\end{array}$} & \multirow[b]{2}{*}{$\begin{array}{l}\text { Streptomycin } \\
{[31] \dagger}\end{array}$} & \multirow[b]{2}{*}{$\begin{array}{l}\text { Amikacin } \\
{[3 I] \dagger}\end{array}$} & \multirow[b]{2}{*}{$\begin{array}{l}\text { Levofloxacin } \\
\text { [3I]† }\end{array}$} & \multirow[b]{2}{*}{$\begin{array}{l}\text { Ofloxacin } \\
{[3 \mathrm{I}] \dagger}\end{array}$} & \multirow[b]{2}{*}{$\begin{array}{l}\text { Increased mutation } \\
\text { rate if absent }\end{array}$} \\
\hline & & & $\begin{array}{l}\text { Exponential } \\
\text { phase growth }\end{array}$ & Dormancy* & $\begin{array}{l}\text { Nutrient } \\
\text { depletion }\end{array}$ & $\begin{array}{l}\text { Progressive } \\
\text { hypoxia }\end{array}$ & & & & & & & \\
\hline Rv0003 & recF & & & - & & - & & & & & & & \\
\hline Rv0054 & $s s b$ & & & & & & + & & & & & & \\
\hline $\mathrm{Rv0269 \textrm {C }}$ & & + & & & & & & & & & & & \\
\hline Rv0427c & $x$ thA & & & & & & & & & & & + & \\
\hline $\mathrm{Rv} 0630 \mathrm{c}$ & $\operatorname{rec} B$ & - & & & & & & & - & & & & \\
\hline Rv0670 & nfo, end & + & & & + & & & & & & & & \\
\hline Rv0938 & $\operatorname{lig} D$ & + & & & & & & & & & & & \\
\hline Rv0944, & nei2 & & & & & & & & & & & & \\
\hline Rv0949 & uvrDI & & & & & & & & & & & & Ms $+[26]$ \\
\hline Rvl02I & $\operatorname{maz} G$ & + & & & & - & & & & & & & \\
\hline $\operatorname{Rv} 1210$ & $\operatorname{tag} A$ & - & & & & & & & & & & + & \\
\hline Rvl259 & $u d g B$ & & & & & & & & & & & & Ms + [II0,II4] \\
\hline Rvl316c & ogt & & & & & & & & & & & + & $+[45]$ \\
\hline Rvi3I7c & ada, alkA & & & & & & & & & & + & + & $+[45]$ \\
\hline Rvl 420 & uvrC & - & & & & & & & & & & & \\
\hline Rvl537 & $\operatorname{din} X$ & & & & + & & & + & & & & & \\
\hline Rvl629 & polA & + & & & & & & & & & & & \\
\hline Rvl633 & uvrB & & & & & & & & & & & + & Ms $+[24,26]$ \\
\hline Rvl638 & uvrA & & & & & & & & & & + & & \\
\hline $\operatorname{Rv} 2191$ & & & & & & & & & & + & & & \\
\hline $\operatorname{Rv} 2592 \mathrm{c}$ & ruvB & & - & & & & & & & & & & \\
\hline $\operatorname{Rv} 2594 c$ & ruvC & & - & & & & & & & & & & \\
\hline $\operatorname{Rv} 2697 c$ & $d u t$ & & & & & & & & & & & & \\
\hline
\end{tabular}


Table 4 (Contd.)

\begin{tabular}{|c|c|c|c|c|c|c|c|c|c|c|c|c|c|}
\hline \multirow[b]{2}{*}{ Locus } & \multirow[b]{2}{*}{ Gene } & \multirow[b]{2}{*}{$\begin{array}{l}\text { Izoniazyd } \\
\text { [103] }\end{array}$} & \multicolumn{4}{|l|}{ Izoniazyd [106] } & \multirow[b]{2}{*}{$\begin{array}{l}\text { Capreomicine } \\
{[104]}\end{array}$} & \multirow[b]{2}{*}{$\begin{array}{l}\text { Rifampicin } \\
{[31] \dagger}\end{array}$} & \multirow[b]{2}{*}{$\begin{array}{l}\text { Streptomycin } \\
{[3 \mathrm{I}] \dagger}\end{array}$} & \multirow[b]{2}{*}{$\begin{array}{l}\text { Amikacin } \\
{[31] \dagger}\end{array}$} & \multirow[b]{2}{*}{$\begin{array}{l}\text { Levofloxacin } \\
{[3 \mathrm{I}] \dagger}\end{array}$} & \multirow[b]{2}{*}{$\begin{array}{l}\text { Ofloxacin } \\
{[31] \dagger}\end{array}$} & \multirow[b]{2}{*}{$\begin{array}{l}\text { Increased mutation } \\
\text { rate if absent }\end{array}$} \\
\hline & & & $\begin{array}{l}\text { Exponential } \\
\text { phase growth }\end{array}$ & Dormancy* & $\begin{array}{l}\text { Nutrient } \\
\text { depletion }\end{array}$ & $\begin{array}{l}\text { Progressive } \\
\text { hypoxia }\end{array}$ & & & & & & & \\
\hline $\operatorname{Rv} 2719 \mathrm{c}$ & & & & & & & & & & & & + & \\
\hline $\operatorname{Rv} 2720$ & $\operatorname{lex} A$ & + & & & & & & & & & & & \\
\hline Rv2737c & recA & & & & & & & & & & & + & \\
\hline $\operatorname{Rv} 2924 c$ & mutM, $f p g$ & - & & & & & & & & & & & Ms $+[24, I 12]$ \\
\hline Rv2973c & recG & - & & & & & & & & & & & \\
\hline Rv2976c & Ung & & & & & & & & & & & & Ms $+[24, \mathrm{II} 0, \mathrm{III}]$ \\
\hline Rv2985 & mutTI & & & & & + & & & & & & & \\
\hline Rv2986c & hupB & & - & & & & & & & & & & \\
\hline Rv3198c & uvrD2 & & & & & & & & & & & & \\
\hline Rv320Ic & $\operatorname{adn} B$ & + & & & & & & & & & & & \\
\hline $\operatorname{Rv} 3202 c$ & $\operatorname{adn} A$ & + & & & & & & & & & & & \\
\hline Rv3296 & Ihr & & & & & & & & & & & + & \\
\hline Rv3297 & nei & & & & & & & & & & & & \\
\hline Rv3395c & $\operatorname{din} F$ & & & & & & & & & & + & & \\
\hline Rv3585 & $\mathrm{radA}$ & & & & & & & & & & & + & \\
\hline $\operatorname{Rv} 3674 c$ & nth & & & & - & & & & & & & & \\
\hline Rv3715c & reck & & - & & & & + & & & + & & & \\
\hline Rv373I & $\operatorname{lig} C$ & - & & & & & & & & & & & \\
\hline Rv3908 & mutT4 & & & & & & & & & & & & \\
\hline
\end{tabular}


survival as they account for the majority of strains identified in many countries [95-99] and both account for a vast number of MDR and XDR strains [98-100]. It has been discovered that many of these drug-resistant strains carry mutations in DNA repair genes, resulting in their mutator phenotype. adalalkA, ogt $[94,101]$ and ung [101] mutations have been discovered in Haarlem lineages, whereas mutT4, mutT2 and ogt have been discovered in W-Beijing lineages $[100,102]$. The same mutations are also observed in non-MDR strains, but this does not negate the point that their mutator phenotype may increase the possibility of them acquiring mutations against anti-tubercular drugs.

Many anti-tubercular compounds influence the expression of DNA repair genes in mycobacteria [29,31,103-106] (Table 4 and Supplementary Table S3), including first- and second-line drugs that are currently used in therapy (Table 4). Although no DNA repair genes were induced in response to the first-line drugs pyrazinamide or ethambutol, under treatment with ofloxacin, an inhibitor of DNA gyrase, ten of them were up-regulated at least 2-fold [31]. It is, thus, a tempting idea that the use of currently applied antibiotics combined with drugs that target the up-regulated DNA repair genes might increase the effectiveness of any chemotherapy. In fact, a recA-deficient mutant of BCG had increased susceptibility to metronidazole in vitro [48], and an ogt mutant of BCG had increased susceptibility to isoniazid [107]. However, it would be important to test such strategies carefully to ensure that the reduction in the activity of DNA repair proteins does not result in an increased mutation rate that could contribute to the generation of drug-resistant strains.

\section{CONCLUSIONS}

DNA repair pathways in mycobacteria are crucial for their survival at different stages of infection. As infection progresses, different sets of genes play an important role in maintaining the stability of the mycobacterial genome. Even though results obtained using different methods are sometimes contradictory, an improved understanding of the role of DNA repair in the pathogenesis of mycobacteria might reveal good candidates for effective treatment against tuberculosis. There is much data regarding the expression of each DNA repair gene in MTB; however, there is still a lot to discover and more studies, especially performed in vivo with MTB, are needed.

\section{FUNDING}

The work was supported by grant from the State Committee for Scientific Research [grant number N303
3582 33]. A. E. G. is partially supported by the European Social Fund and the national budget of Poland.

\section{REFERENCES}

1 World Health Organization (2009) Global tuberculosis control: epidemiology, strategy, financing, WHO Report 2009, WHO, Geneva

2 Cooper, A. M. (2009) Cell mediated immune responses in tuberculosis. Annu. Rev. Immun. 27, 393-422

3 Friedberg, E. C. (2003) DNA damage and repair. Nature 421, 436-440

4 Warner, D. F. and Mizrahi, V. (2006) Tuberculosis chemotherapy: the influence of bacillary stress and damage response pathways on drug efficacy. Clin. Microbiol. Rev. 19, 558-570

5 Springer, B., Sander, P., Sedlacek, L., Hardt, W. D., Mizrahi, V., Schär, P. and Böttger, E. C. (2004) Lack of mismatch correction facilitates genome evolution in mycobacteria. Mol. Microbiol. 53, 1601-1609

6 Davis, E. O. and Forse, L. N. (2009) DNA repair: key to survival? In Mycobacterium, Genomics and Molecular Biology (Parish, T., and Brown, A., eds), pp, 79-117, Caister Academic Press, Norwich

7 Dos Vultos, T., Mestre, O., Tonjum, O. and Gicquel, B. (2009) DNA repair in Mycobacterium tuberculosis revisited. FEMS Microbiol. Rev. 33, 471-487

8 Fu, L. M. and Fu-Liu, C. S. (2007) The gene expression data of Mycobacterium tuberculosis based on Affymetrix gene chips provide insight into regulatory and hypothetical genes. BMC Microbiol. 7, 37

9 Sassetti, C. M., Boyd, D. H. and Rubin, E. J. (2003) Genes required for mycobacterial growth defined by high density mutagenesis. Mol. Microbiol. 48, 77-84

10 Sinha, K. M., Stephanou, N. C., Unciuleac, M. C., Glickman, M. S. and Shuman, S. (2008) Domain requirements for DNA unwinding by mycobacterial UvrD2, an essential DNA helicase. Biochemistry 47, 9355-9364

11 Korycka-Machala, M., Brzostek, A., Rozalska, S., Rumijowska-Galewicz, A., Dziedzic, R., Bowater, R. and Dziadek, J. (2006) Distinct DNA repair pathways involving RecA and nonhomologous end joining in Mycobacterium smegmatis. FEMS 258, 83-91

12 Sassetti, C. M. and Rubin, E. J. (2003) Genetic requirements for mycobacterial survival during infection. Proc. Natl. Acad. Sci. U.S.A. 100, 12989-12994

13 Fennelly, K. P., Martyny, J. W., Fulton, K. E., Orme, I. M., Cave, D. M. and Heifets, L. B. (2004) Cough-generated aerosols of Mycobacterium tuberculosis, a new method to study infectiousness. Am. J. Respir. Crit. Care Med. 169, 604-609

14 Loudon, R. G., Bumgarner, L. R., Lacy, J. and Coffman, G. K. (1969) Aerial transmission of mycobacteria. Am. Rev. Resp. Dis. 100, 165-171

15 Lever, M. S., Williams, A. and Bennett, A. M. (2000) Survival of mycobacterial species in aerosols generated from artificial saliva. Lett. App. Microbiol. 31, 238-241

16 Ko, G., First, M. W. and Burge, H. A. (2002) The characterization of upper-room ultraviolet germicidal irradiation in inactivating airborne microorganisms. Environ. Health Perspect. 110, 95-101

17 Peccia, J. and Hernandez, M. (2004) UV-induced inactivation rates for airborne Mycobacterium bovis BCG. J. Occupat. Environ. Hyg. 1, 430-435

18 Riley, R. L., Knight, M. and Middlebrook, G. (1976) Ultraviolet susceptibility of BCG and virulent tubercle bacilli. Am. Rev. Respir. Dis. 113, 413-418 
19 Saito, M., Pan, W. K., Gilman, R. H., Bautista, C. T., Bamrah, S., Martin, C. A., Tsiouris, S. J., Arguello, D. F. and Martinez-Carrasco, G. (2006) Comparison of altitude effect on Mycobacterium tuberculosis infection between rural and urban communities in Peru. Am. J. Trop. Med. Hyg. 75, 49-54

20 Ko, G., First, M. W. and Burge, H. A. (2000) Influence of relative humidity on particle size and UV sensitivity of Serratia marcescens and Mycobacterium bovis BCG aerosols. Tuberc. Lung Dis. 80, 217-228

21 Peccia, J. L., Werth, H. M. and Hernandez, M. T. (2000) Effects of relative humidity on the UV-induced inactivation of bacterial bioaerosols. J. Aerosol. Sci. 31, 959-960

22 Pitcher, R. S., Green, A. J., Brzostek, A., Korycka-Machala, M., Dziadek, J. and Doherty, A. J. (2007) NHEJ protects mycobacteria in stationary phase against the harmful effects of desiccation. DNA Repair 6, 1271-1276

23 Gordhan, B. G., Andersen, S. J., De Meyer, A. R. and Mizrahi, V. (1996) Construction by homologous recombination and phenotypic characterization of a DNA polymerase domain $p o I A$ mutant of Mycobacterium smegmatis. Gene 178, 125-130

24 Kurthkoti, K., Kumar, P., Jain, R. and Varshney, U. (2008) Important role of the nucleotide excision repair pathway in Mycobacterium smegmatis in conferring protection against commonly encountered DNA damaging agents. Microbiology 154, 2776-2785

25 Darwin, K. H. and Nathan, C. F. (2005) Role for nucleotide excision repair in virulence of Mycobacterium tuberculosis. Infect. Immun. 73, 4581-4587

26 Guthlein, C., Wanner, R. M., Sander, P., Davis, E. O., Bosshard, M., Jiricny, J., Bottger, E. C. and Springer, B. (2009) Characterization of the mycobacterial NER system reveals novel functions of the $u v r D 1$ helicase. J. Bacteriol. 191, 555-562

27 Sinha, K. M., Stephanou, N. C., Gao, F., Glickman, M. S. and Shuman, S. (2007) Mycobacterial UvrD1 is a $\mathrm{Ku}$-dependent DNA helicase that plays a role in multiple DNA repair events, including double- strand break repair. J. Biol. Chem. 282, 15114-15125

28 Stephanou, N. C., Gao, F., Bongiorno, P., Ehrt, S., Schnappinger, D., Shuman, S. and Glickman, M. S. (2007) Mycobacterial nonhomologous end joining mediates mutagenic repair of chromosomal double-strand DNA breaks. J. Bacteriol. 189, 5237-5246

29 Movahedzadeh, F., Colston, M. J. and Davis, E. O. (1997) Determination of DNA sequences required for regulated Mycobacterium tuberculosis RecA expression in response to DNA-damaging agents suggests that two modes of regulation exist. J. Bacteriol. 179, 3509-3518

30 Frischkorn, K., Sander, P., Scholz, M., Teschner, K., Prammananan, T. and Bottger, E. (1998) Investigation of mycobacterial RecA function: protein introns in the RecA of pathogenic mycobacteria do not affect competency for homolous recombination. Mol. Microbiol. 29, 1203-1214

31 Boshoff, H. I. M., Myers, T. G., Copp, B. R., McNeil, M. R., Wilson, M. A. and Barry, C. E. (2004) The transcriptional responses of Mycobacterium tuberculosis to inhibitors of metabolism: novel insights into drug mechanisms of action. J. Biol. Chem. 279, 40174-40184

32 Boshoff, H. I. M., Reed, M. B., Barry, C. E. and Mizrahi, V. (2003) DnaE2 polymerase contributes to in vivo survival and the emergence of drug resistance in Mycobacterium tuberculosis. Cell 113, 183-193

33 Mulder, M. A., Nair, S., Abratt, V. R., Zappel, H. and Steyn, L. M. (1999) Involvement of the N- and C-terminal domains of Mycobacterium tuberculosis KatG in the protection of mutant Escherichia coli against DNA-damaging agents. Microbiology 145, 2011-2021
34 Adams, L. B., Dinauer, M. C., Morgenstern, D. E. and Krahenbuhl, J. L. (1997) Comparison of the roles of reactive oxygen and nitrogen intermediates in the host response to Mycobacterium tuberculosis using transgenic mice. Tuber. Lung Dis. 78, 237-246

35 Chan, J., Tanaka, K., Carrol, D., Flynn, J. and Bloom, B. R. (1995) Effects of nitric oxide synthase inhibitors on murine infection with Mycobacterium tuberculosis. Infect. Immun. 63, 736-740

36 MacMicking, J. D., North, R. J., LaCourse, R., Mudgett, J. S., Shah, S. K. and Nathan, C. F. (1997) Identification of nitric oxide synthase as a protective locus against tuberculosis. Proc. Natl. Acad. Sci. U.S.A. 94, 5243-5248

37 Burney, S., Caulfield, J. L., C. Niles, C. J., Wishnok, J. S. and Tannenbaum, S. R. (1999) The chemistry of DNA damage from nitric oxide and peroxynitrite. Mutat. Res. 424, 37-49

38 Wiseman, H. and Halliwell, B. (1996) Damage to DNA by reactive oxygen and nitrogen species: role in inflammatory disease and progression to cancer. Biochem. J. 313, 17-29

39 Krokan, H. E., Standal, R. and Slupphaug, G. (1997) DNA glycosylases in the base excision repair of DNA. Biochem. J. 325, 1-16

40 Gaynor, C. D., McCormack, F. X., Voelker, D. R., McGowan, S. E. and Schlesinger, L. S. (1995) Pulmonary surfactant protein A mediates enhanced phagocytosis of Mycobacterium tuberculosis by a direct interaction with human macrophages J. Immun. 155, 5343-5351

41 Weikert, L. F., Lopez, J. P., Abdolrasulnia, R., Chroneos, Z. C. and Shepherd, V. L. (2000) Surfactant protein A enhances mycobacterial killing by rat macrophages through a nitric oxide-dependent pathway. Am. J. Physiol. Lung Cell. Mol. Physiol. 279, L216-L223

42 Schwab, U., Rohde, K. H., Wang, Z., Chess, P. R., Notter, R. H. and Russell, D. G. (2009) Transcriptional responses of Mycobacterium tuberculosis to lung surfactant. Microb. Pathog. 46, 185-193

43 Fontan, P., Aris, V., Ghanny, S., Soteropoulos, P. and Smith, I. (2008) Global transcriptional profile of Mycobacterium tuberculosis during THP-1 human macrophage infection. Infect. Immun. 76, 717-725

44 Schnappinger, D., Ehrt, S., Voskuil, M. I., Liu, Y., Mangan, J. A., Monahan, I. M., Dolganov, G., Efron, B., Butcher, P. D., Nathan, C. and Schoolnik, G. K. (2003) Transcriptional adaptation of Mycobacterium tuberculosis within macrophages: insights into the phagosomal environment. J. Exp. Med. 198, 693-704

45 Durbach, S. I., Springer, B., Machowski, E. E., North, R. J., Papavinasasundaram, K. G., Colston, J., Bottger, E. C. and Mizrahi, V. (2003) DNA alkylation damage as a sensor of nitrosative stress in Mycobacterium tuberculosis. Infect. Immun. 71, 997-1000

45a Darwin, K. H., Ehrt, S., Gutierrez- Ramos, J. C., Weich, N. and Nathan, C. F. (2003) The proteasome of Mycobacterium tuberculosis is required for resistance to nitric oxide. Science 302, 1963-1966

46 Dubnau, E., Fontan, P., Manganelli, R., Soares-Appel, S. and Smith, I. (2002) Mycobacterium tuberculosis genes induced during infection of human macrophages. Infect. Immun. 70, 2787-2795

47 Talaat, A. M., Lyons, R., Howard, S. T. and Johnston, S. A. (2004) The temporal expression profile of Mycobacterium tuberculosis infection in mice. Proc. Natl. Acad. Sci. U.S.A. 101, 4602-4607

48 Sander, P., Papavinasasundaram, K. G., Dick, T., Stavropoulos, E., Ellrot, K., Springer, B., Colston, M. J. and Bottger, E. C. (2001) Mycobacterium bovis BCG recA deletion mutant shows increased susceptibility to DNA-damaging agents but wild-type survival in a mouse infection model. Infect. Immun. 69, 3562-3568 
49 Tsai, M. C., Chakravarty, S., Zhu, G., Xu, J., Tanaka, K., Koch, C., Tufariello, J., Flynn, J. and Chan, J. (2006) Characterization of the tuberculous granuloma in murine and human lungs: cellular composition and relative tissue oxygen tension. Cell. Microbiol. 8, 218-232

50 Aly, S., Wagner, K., Keller, C., Malm, S., Malzan, A., Brandau, S., Bange, F.-C. and Ehlers, S. (2006) Oxygen status of lung granulomas in Mycobacterium tuberculosis-infected mice. J. Pathol. 210, 298-305

51 Saunders, B. M. and Britton, W. J. (2007) Life and death in the granuloma: immunopathology of tuberculosis. Immun. Cell Biol. 85, 103-111

52 Smeulders, M. J., Keer, J., Speight, R. A. and Williams, H. D. (1999) Adaptation of Mycobacterium smegmatis to stationary phase. J. Bacteriol. 181, 270-283

53 Munoz-Elias, E. J., Timm, J., Botha, T., Chan, W. T., Gomez, J. E. and McKinney, J. D. (2005) Replication dynamics of Mycobacterium tuberculosis in chronically infected mice. Infect. Immun. 73, 546-551

54 Moller, P., Loft, S., Lundby, C. and Olsen, N. V. (2001) Acute hypoxia and hypoxic exercise induce DNA strand breaks and oxidative DNA damage in humans. FASEB J. 15, 1181-1186

55 Grishko, V., Solomon, M., Breit, J. F., Killilea, D. W., LeDoux, S. P., Wilson, G. L. and Gillespie, M. N. (2001) Hypoxia promotes oxidative base modifications in the pulmonary artery endothelial cell VEGF gene. FASEB J. 15, 1267-1269

56 Kim, S. Y., Lee, B. S., Shin, S. J., Kim, H. J. and Park, J. K. (2008) Differentially expressed genes in Mycobacterium tuberculosis $\mathrm{H} 37 \mathrm{Rv}$ under mild acidic and hypoxic conditions. J. Med. Microbiol. 57, 1473-1480

57 Bacon, J., James, B. W., Wernisch, L., Williams, A., Morleya, K. A., Hatch, G. J., Mangan, J. A., Hinds, J., Stoker, N. G., Butcher, P. D. and Marsh, P. D. (2004) The influence of reduced oxygen availability on pathogenicity and gene expression in Mycobacterium tuberculosis. Tuberculosis 84, 205-217

58 Muttucumaru, D. G. N., Roberts, G., Hinds, J., Stabler, R. A. and Parish, T. (2004) Gene expression profile of Mycobacterium tuberculosis in a non-replicating state. Tuberculosis 84, 239-246

59 Voskuil, M. I., Visconti, K. C. and Schoolnik, G. K. (2004) Mycobacterium tuberculosis gene expression during adaptation to stationary phase and low-oxygen dormancy. Tuberculosis 84, 218-227

60 Betts, J. C., Lukey, P. T., Robb, L. C., McAdam, R. A. and Duncan, K. (2002) Evaluation of a nutrient starvation model of Mycobacterium tuberculosis persistence by gene and protein expression profiling. Mol. Microbiol. 43, 717-731

61 Hampshire, T., Soneji, S., Bacon, J., James, B. W., Hinds, J., Laing, K., Stabler, R. A., Marsh, P. D. and Butcher, P. D. (2004) Stationary phase gene expression of Mycobacterium tuberculosis following a progressive nutrient depletion: a model for persistent organisms? Tuberculosis 84, 228-238

62 Chan, E. D., Chan, J. and Schluger, N. W. (2001) What is the role of nitric oxide in murine and human host defense against tuberculosis? Am. J. Respir. Cell Mol. Biol. 25, 606-612

63 Voskuil, M. I., Schanppinger, D., Visconti, K. C., Harrell, M. I., Dolganov, G. M., Sherman, D. R. and Schoolnik, G. K. (2003) Inhibition of respiration by nitric oxide induces a Mycobacterium tuberculosis dormancy program. J. Exp. Med. 198, 705-713

64 Karakousis, P. C., Yoshimatsu, T., Lamichhane, G., Woolwine, S. C., Nuermberger, E. L., Grosset, J. and Bishai, W. R. (2004) Dormancy phenotype displayed by extracellular Mycobacterium tuberculosis within artificial granulomas in mice. J. Exp. Med. 200, 647-657
65 Kesavan, A. K., Brooks, M., Tufariello, J., Chan, J. and Manabe, Y. C. (2009) Tuberculosis genes expressed during persistence and reactivation in the resistant rabbit model. Tuberculosis 89,17-21

66 Talaat, A. M., Ward, S. K., Wu C.W., Rondon, E., Tavano, C., Bannantine, J. P., Lyons, R. and Johnston, S. A. (2007) Mycobacterial bacilli are metabolically active during chronic tuberculosis in murine lungs: insights from genome-wide transcriptional profiling. J. Bacteriol. 189, 4265-4274

67 Rachman, H., Strong, M., Ulrichs, T., Grode, L., Schuchhardt, J., Mollenkopf, H., Kosmiadi, G. A., Eisenberg, D. and Kaufmann, S. H. E. (2006) Unique transcriptome signature of Mycobacterium tuberculosis in pulmonary tuberculosis. Infect. Immun. 74, 1233-1242

68 Karunkaran, P. and Davies, J. (2000) Genetic antagonism and hypermutability in Mycobacterium smegmatis. J. Bacteriol. 182, 3331-3335

69 Martinez, J. L. and Baquero, F. (2000) Mutation frequencies and antibiotic resistance. Antimicrob. Agents Chemother. 44, 1771-1777

70 Katti, M. K. (2001) Plasmids of mycobacteria. J. Med. Microbiol. 50, 575-576

71 Zainuddin, Z. F. and Dale, J. W. (1990) Does Mycobacterium tuberculosis have plasmids? Tubercle 71, 43-49

72 Nguyen, K. T., Piastro, K. and Derbyshire, K. M. (2009) LpqM, a mycobacterial lipoprotein-metalloproteinase, is required for conjugal DNA transfer in Mycobacterium smegmatis. J. Bacteriol. 191, 2721-2727

73 Flint, J. L., Kowalski, J. C., Karnati, P. K. and Derbyshire, K. M. (2004) The RD1 virulence locus of Mycobacterium tuberculosis regulates DNA transfer in Mycobacterium smegmatis. Proc. Natl. Acad. Sci. U.S.A. 101, 12598-12603

74 Filliol, I., Motiwala, A. S., Cavatore, M., Qi, W., Hazbon, M. H., Bobadilla del Valle, M., Fyfe, J., Garcia-Garcia, L. Rastogi, N., Sola, C. et al. (2006) Global phylogeny of Mycobacterium tuberculosis based on single nucleotide polymorphism (SNP) analysis: insights into tuberculosis evolution, phylogenetic accuracy of other DNA fingerprinting systems, and recommendations for a minimal standard SNP set. J. Bacteriol. 188, 759-772

75 Cubillos-Ruiz, A., Morales, J. and Zambrano, M. M. (2008) Analysis of the genetic variation in Mycobacterium tuberculosis strains by multiple genome alignments. BMC Res. Notes 1, 110

76 Arnold, C., Westland, L., Mowat, G., Underwood, A., Magee, J. and Gharbia, S. (2005) Single-nucleotide polymorphism-based differentiation and drug resistance detection in Mycobacterium tuberculosis from isolates or directly from sputum. Clin. Microbiol. Infect. 11, 122-130

77 Tang, X., Morris, S. L., Langone, J. J. and Bockstahler, L. E. (2005) Microarray and allele specific PCR detection of point mutations in Mycobacterium tuberculosis genes associated with drug resistance. J. Microbiol. Methods 63, 318-330

78 Zaczek, A., Brzostek, A., Augutynowicz-Kopec, E. Zwolska, Z. and Dziadek, J. (2009) Genetic evaluation of relationship between mutations in $r p o B$ and resistance of Mycobacterium tuberculosis to rifampin. BMC Microbiol. 9,10

79 Bostanabad, S. Z., Titov, L. P., Bahrmand, A. and Nojoumi, S. A. (2008) Detection of mutation in izoniazyd resistant Mycobacterium tuberculosis isolates from tuberculosis patients in Belarus. Ind. J. Clin. Microb. 26, $143-147$

80 Ramaswamy, S. V., Reich, R., Dou, S. J., Jasperse, L., Pan, X., Wanger, A., Quitugua, T. and Graviss, E. A. (2003) Single nucleotide polymorphisms in genes associated with isoniazid resistance in Mycobacterium tuberculosis. Antimicrob. Agents Chemother. 47, 1241-1250 
81 Vilcheze, C., Wang, F., Arai, M., Hazbon, M. H., Colangeli, R., Kremer, L., Weisbrod, T. R., Alland, D., Sacchettini, J. C. and Jacobs, Jr, W. R. (2006) Transfer of a point mutation in Mycobacterium tuberculosis inhA resolves the target of isoniazid. Nat. Med. 12, 1027-1029

82 Hazbon, M. H., Motiwala, A. S., Cavatore, M., Brimacombe, M., Whittam, T. S. and Alland, D. (2008) Convergent evolutionary analysis identifies significant mutations in drug resistance targets of Mycobacterium tuberculosis. Antimicrob. Agents Chemother. 52, 3369-3376

83 Srivastava, S., Garg, A., Ayyagari, A., Nyati, K. K., Dhole, T. N. and Dwivedi, S. K. (2006) Nucleotide polymorphism associated with ethambutol resistance in clinical isolates of Mycobacterium tuberculosis. Curr. Microbiol. 53, 401-405

84 Sherman, D. R., Mdluli, K., Hickey, M. J., Arain, T. M., Morris, S. L., Barry III, C. L. and Stover, C. K. (1996) Compensatory ahpC gene expression in isoniazidresistant Mycobacterium tuberculosis. Science 272, 1641-1643

85 Afanasev, M. V., Ikryannikova, L. N., Ilina, N. E., Sidorenko, S. V., Kuzmin, A. V., Larionova, E. E., Smirnova, T. G., Chernousova, L. N., Kamaev, E. Y., Skorniakov, S. N. et al. (2007) Molecular characteristics of rifampicin- and isoniazid-resistant Mycobacterium tuberculosis isolates from the Russian Federation. J. Antimicr. Chemother. Adv. 59, 1057-1064

86 Cheng, S., Thibert, L., Sanchez, T., Heifets, L. and Zhang, Y. (2000) PncA mutations as a major mechanism of pyrazinamide resistance in Mycobacterium tuberculosis: spread of a monoresistant strain in Quebec, Canada. Antimicrob. Agents Chemother. 44, 528-532

87 Fleischmann, R. D., Alland, D., Eisen, J. A., Carpenter, L., White, O., Peterson, J., DeBoy, R., Dodson, R., Gwinn, M., Haft, D. et al. (2002) Whole-genome comparison of Mycobacterium tuberculosis clinical and laboratory strains. J. Bacteriol. 184, 5479-5490

88 Hughes, A. L., Friedman, R. and Murray, M. (2002) Genomewide pattern of synonymous nucleotide substitution in two complete genomes of Mycobacterium tuberculosis. Emerg. Infect. Dis. 8, 1342-1346

89 Kapur, V., Whittam, T. S. and Musser, J. M. (1994) Is Mycobacterium tuberculosis 15,000 years old? J. Infect. Dis. 170, 1348-1349

90 Niemann, S., Koser, C. U., Gagneux, S., Plinke, C., Homolka, S., Bignell, H., Carter, R. J., Cheetham, R. K., Cox, A., Gormley, N. A. et al. (2009) Genomic diversity among drug sensitive and multidrug resistant isolates of Mycobacterium tuberculosis with identical DNA fingerprints. PLoS ONE 4, e7407

91 Das, S., Yennamalli, R., Vishnoi, A., Gupta, P. and Bhattacharya, A. (2009) Single-nucleotide variations associated with Mycobacterium tuberculosis KwaZulu-Natal strains. J. Biosci. 34, 397-404

92 Bergval, I. L., Klatser, P. R., Schuitema, A. R. J., Oskam, L. and Anthony, R. M. (2007) Specific mutations in the Mycobacterium tuberculosis rpoB gene are associated with increased dnaE2 expression. FEMS Microbiol. Lett. 275, 338-242

93 Kurthkoti, K., Srinath, T., Kumar, P., Malshetty, V. S., Sang, P. B., Jain, R., Manjunath, R. and Varshney, U. (2009) A distinct physiological role of MutY in mutation prevention in mycobacteria. Microbiology $156,88-93$

94 Nouvel, L. X., Kassa-Kelembho, E., Dos Vultos, T., Zandanga, G., Rauzier, J., Lafoz, C., Martin, C., Blazquez, J., Talarmin, A. and Gicquel, B. (2006) Multidrug-resistant Mycobacterium tuberculosis, Bangui, Central African Republic. Emerg. Infect. Dis. 12, 1454-1456
95 Banu, S., Gordon, S. V., Palmer, S., Islam, R., Ahmed, S., Alam, K. M., Cole, S. T. and Brosch, R. (2004) Genotypic analysis of Mycobacterium tuberculosis in Bangladesh and prevalence of the Beijing strain. J. Clin. Microbiol. 42, 674-682

96 Jiao, W., Mokrousov, I., Sun, G., Liu, J., Narvskaya, O. and Shen, A. (2007) Molecular characteristics of rifampin and isoniazid resistant Mycobacterium tuberculosis strains from Beijing, China. Chin. Med. J. 120, 814-819

97 Mokrousov, I., Valcheva, V., Sovhozova, N., Aldashev, A., Rastogi, N. and Isakova, J. (2009) Penitentiary population of Mycobacterium tuberculosis in Kyrgyzstan: exceptionally high prevalence of the Beijing genotype and its Russia-specific subtype. Infect. Genet. Evol. 9, 1400-1405

98 Nikolayevskyy, V. V., Brown, T. J., Bazhora, Y. I., Asmolov, A. A., Balabanova, Y. M. and Drobniewski, F. A. (2007) Molecular epidemiology and prevalence of mutations conferring rifampicin and isoniazid resistance in Mycobacterium tuberculosis strains from the southern Ukraine. Clin. Microbiol. Infect. 13,129-138

99 Farnia, P., Masjedi, M. R., Mirsaeidi, M., Mohammadi, F., Ghanavi, J., Vincent, V., Bahadori, M. and Velayati, A. A. (2006) Prevalence of Haarlem I and Beijing types of Mycobacterium tuberculosis strains in Iranian and Afghan MDR-TB patients. J. Infect. 53, 331-336

100 Rad, M. E., Bifani, P., Martin, C., Kremer, K., Samper, S., Rauzier, J., Kreiswirth, B., Blazquez, J., Jouan, M., van Soolingen, D. and Gicquel, B. (2003) Mutations in putative mutator genes of Mycobacterium tuberculosis strains of the W-Beijing family. Emerg. Infect. Dis. 9, 838-845

101 Olano, J., Lopez, B., Reyes, A., Lemos, M. P., Correa, N., Del Portillo, P., Barrera, L., Robledo, J., Ritacco, V. and Zambrano, M. M. (2007) Mutations in DNA repair genes are associated with the Haarlem lineage of Mycobacterium tuberculosis independently of their antibiotic resistance. Tuberculosis 87, 502-508

102 Lari, N., Rindi, L., Bonanni, D., Tortoli, E. and Garzelli, C. (2006) Mutations in mutT genes of Mycobacterium tuberculosis isolates of Beijing genotype. J. Med. Microbiol. 55, 599-603

103 Waddell, S. J., Stabler, R. A., Laing, K., Kremer, L., Reynolds, R. C. and Besra, G. S. (2004) The use of microarray analysis to determine the gene expression profiles of Mycobacterium tuberculosis in response to anti-bacterial compounds. Tuberculosis 84, 263-274

$104 \mathrm{Fu}, \mathrm{L}$. M. and Shinnick, T. M. (2007) Genome-wide exploration of the drug action of capreomycin on Mycobacterium tuberculosis using Affymetrix oligonucleotide GeneChips. J. Infect. 54, 277-284

105 O’Sullivan, D. M., Hinds, J., Butcher, P. D., Gillespie, S. H. and McHugh, T. D. (2008) Mycobacterium tuberculosis DNA repair in response to subinhibitory concentrations of ciprofloxacin. J. Antimicrob. Chemother. 62, 1199-1202

106 Karakousis, P. C., Williams, E. P. and Bishai, W. R. (2008) Altered expression of isoniazid-regulated genes in drug-treated dormant Mycobacterium tuberculosis. J. Antimicrob. Chemother. 61, 323-331

107 Wiid, I., Grundlingh, R., Bourn, W., Bradley, G., Harington, A., Hoal-van Helden, E. G. and van Helden, P. (2002) $\mathrm{O}^{6}$-alkylguanine-DNA alkyltransferase DNA repair in mycobacteria: pathogenic and non-pathogenic species differ. Tuberculosis 82, 45-53

108 Capelli, G., Volpe, E., Grassi, M., Liseo, B., Colizzi, V. and Mariani, F. (2006) Profiling of Mycobacterium tuberculosis gene expression during human macrophage infection: upregulation of the alternative sigma factor $\mathrm{G}$, a group of transcriptional regulators, and proteins with unknown function. Res. Microbiol. 157, 445-455 
109 Rachman, H., Strong, M., Schaible, U., Schuchhardt, J., Hagens, K., Mollenkopf, H., Eisenberg, D. and Kaufmann, S. H. E. (2006) Mycobacterium tuberculosis gene expression profiling within the context of protein networks. Microbes Infect. 8, 747-757

110 Malshetty, V. S., Jain, R., Srinath, T., Kurthkoti, K. and Varshney, U. (2010) Synergistic effects of UdgB and Ung in mutation prevention and protection against commonly encountered DNA damaging agents in Mycobacterium smegmatis. Microbiology 156, 940-949

111 Venkatesh, J., Kumar, P., Krishna, P. S. M., Manjunath, R. and Varshney, U. (2003) Importance of uracil DNA glycosylase in Pseudomonas aeruginosa and Mycobacterium smegmatis, G+C-rich bacteria, in mutation prevention, tolerance to acidified nitrite, and endurance in mouse macrophages. J. Biol. Chem. 278, 24350-24358
112 Jain, R., Kumar, P. and Varshney, U. (2007) A distinct role of formamidopyrimidine DNA glycosylase (MutM) in down-regulation of accumulation of G, C mutations and protection against oxidative stress in mycobacteria. DNA Repair 6, 1774-1785

113 Graham, J. and Clark-Curtiss, J. E. (1999) Identification of Mycobacterium tuberculosis RNAs synthesized in response to phagocytosis by human macrophages by selective capture of transcribed sequences (SCOTS). Proc. Natl. Acad. Sci. U.S.A. 96, 11554-11559

114 Wanner, R. M., Castor, D., Guthlein, C., Bottger, E. C., Springer, B. and Jiricny, J. (2009) The uracil DNA glycosylase UdgB of Mycobacterium smegmatis protects the organism from the mutagenic effects of cytosine and adenine deamination. J. Bacteriol. 191, 6312-6319 